\title{
Sociocultural Theory, the L2 Writing Process, and Google Drive: Strange Bedfellows?
}

Nikolay Slavkov

This article draws on sociocultural theory and the process approach to writing as familiar and widely used elements of second language pedagogy that can be leveraged in interesting new ways through the use of digital technology. The focus is on a set of affordances offered by Google Drive, a popular online storage and document-sharing technology. On the assumption that dynamic collaboration with peers, teacher feedback, and authentic computer-mediated tasks contribute to the development of writing skills, Google Drive can be seen as an effective tool for meaningful and cost-effective technology-enriched instruction that entails potential advances in pedagogical practice. An overview of the app's user-friendly interface is provided from a nonspecialist perspective, followed by a discussion of how one may go about organizing a writing course using the tool in a language lab or online. Specific examples of tasks used in ESL courses at a North American postsecondary institution are included.

Cet article puise dans la théorie socioculturelle et l'approche à l'écriture par processus, des concepts bien connus et répandus en enseignement $L 2$ et dont on peut tirer parti de façons innovatrices grâce à la technologie numérique. Notre étude porte sur les capacités de Google Drive, une technologie populaire qui permet le stockage en ligne et le partage de documents. Tenant comme acquis que la collaboration dynamique avec les pairs, la rétroaction de la part des enseignants et les tâches authentiques assistées par ordinateur contribuent au développement des compétences en écriture, nous présentons Google Drive comme un outil technologique efficace et rentable qui vient enrichir la pédagogie de l'enseignement authentique. Nous offrons un aperçu de l'interface conviviale de l'application du point de vue d'un non-spécialiste pour ensuite discuter de la façon d'organiser, dans un laboratoire d'informatique ou en ligne, un cours d'écriture avec Google Drive. Des exemples spécifiques de tâches employées dans des cours d'ALS dans une institution post-secondaire en Amérique du Nord sont présentés.

Sociocultural theory and the process approach to writing are two related and well-known aspects of modern second language pedagogy. The former capitalizes on the idea that learning is socially situated and best achieved through collaboration with and dialogic feedback from peers and teachers. The latter views writing instruction as a form of continuous engagement with students throughout the entire process of planning, drafting, revising, editing, and distribution, as opposed to requiring students to submit a single final draft for feedback and evaluation. With regard to the use of technology, writing instruc- 
tion has long benefited from word-processing software (e.g. Microsoft Word), which offers convenient drafting and editing tools and reduces or replaces the use of pencil-and-paper tasks. However, with the boom of 21st-century technological applications (apps) using online creation, storage, and sharing of documents across platforms, devices, and users, a set of new affordances for enhancing writing instruction has become available. These affordances go well beyond the scope of traditional word-processing. In this article I focus on Google Drive, a popular online storage and sharing technology, and argue that even though it was not designed with writing instruction in mind, it can serve as a rich instructional medium consistent with the goals and assumptions of sociocultural theory and the process approach to writing. As such, instructors who are interested in enhancing sociocultural and process-oriented approaches may wish to draw on Google Drive in course design.

The rest of this article is organized as follows. In the next section, I offer an overview of sociocultural theory and relate it to the process approach to writing. Then I provide a description of Google Drive's main features and outline the new affordances that it brings to writing instruction. I offer a sample course organization template for writing instruction with Google Drive and provide specific examples of tasks exploiting the tool's affordances. I conclude with a discussion of the tool's potential to strengthen sociocultural views related to writing instruction, challenge, and perhaps redefine some existing concepts and practices in new and interesting ways.

\section{Sociocultural Theory and the Process Approach to Writing}

Sociocultural theory has had a significant impact in education and second language teaching. Even though current sociocultural views are multifaceted, they typically draw on Vygotsky's $(1978,1986)$ idea that higher-order cognitive processes are socially mediated within specific cultural contexts and best understood when investigated within the course of historical development. A commonly cited Vygotskian notion is the zone of proximal development (ZPD), whereby "the distance between the actual developmental level as determined by independent problem solving" is linked to "the level of potential development as determined through problem solving under adult guidance, or in collaboration with more capable peers" (Vygotsky, 1978, p. 86).

Turning specifically to writing within a sociocultural perspective, recent characterizations describe it as a type of social act that involves a complex dialogic and distributed process of invention and knowledge transformation, mediated by cultural and historical artefacts (Bazerman \& Prior, 2004; Behizadeh, 2014; Dyson, 1993, 1997; Prior, 2006; Razafar \& Gutierrez, 2003; Rish, Bylen, Vreeland, \& Wimberley, 2015; Schultz \& Fecho, 2000). Rish et al. (2015) categorize these ideas into four main tenets of a conceptionalization of a sociocultural theory of writing. The first tenet refers to writing as a social act and maintains that social contexts shape both the way in which authors 
write and the content of their writing. Writing does not occur in a vacuum but is affected by social relationships, institutional belongings, membership in various communities, and so on. The second tenet assumes that authorship is not solitary but distributed. That is, through writing, an author interacts in multiple ways and on multiple levels with others in a "process of invention and transcription," and those interactions affect the content and style of writing (Rish et al., 2015, p. 359). On this view, writing is always collaborative and essentially constitutes a form of coauthorship. For example, Prior (2006) argues that teachers are in many ways coauthors in their students' writing, as they may help identify topics, provide advice on organization and style, give feedback on sentence and word level aspects, and so on.

The third tenet of the conceptualization of a sociocultural theory of writing, as discussed by Rish et al. (2015), is that writing is a mediated process of invention. During this process, writers use a number of resources or tools that may inform or influence the nature and content of writing. The fourth tenet refers to the notions of dialogism and intertextuality (Bakhtin, 1981). In a broad sense, these two notions refer to authors lending and borrowing ideas, linguistic structures and lexical material to and from complex networks of other writers, texts, and discourses.

On a more tangible level, writing is dialogic in a classroom context, for example, as it often involves pair or small group work with collaborative prewriting activities, feedback on different drafts, revisions, sharing of texts that are in progress or completed, and so on.

While the above tenets of a sociocultural theory of writing were not necessarily conceived with second language writing in mind, they apply to such contexts as well. What is different in the case of L2 settings is that the learners, in addition to participating in the processes described in the four tenets above, are also at various stages of learning the linguistic, sociopragmatic and cultural norms or conventions of the target environment. A large body of literature on second language pedagogy discusses the relevance and impact of sociocultural theory in L2 learning (e.g., Eun \& Lim, 2009; Lantolf, 1994, 2000; Lantolf \& Thorne, 2006; Yoon \& Kim, 2012). In addition, second language writing has been investigated by various scholars (for overviews, see, e.g., Ferris \& Hedgcock, 2013; Leki, Cumming, \& Silva, 2008; Matsuda, 2003; Villamil \& de Guerrero, 2006; Weigle, 2014; Williams, 2005).

Current classroom views and practices often emphasize the dynamic nature of writing. A number of researchers and practitioners have argued that writing should be regarded as a process rather than a product (e.g., Ferris \& Hedgcock, 2013; Peñuelas, 2008; Sasaki, 2000; Weigle, 2005, 2014; White \& Arndt, 1991; however, see Kalan, 2014, and Hyland, 2003, for postprocess approaches to writing). That is, instructors are encouraged to set up a collaborative process that takes learners through sets of prewriting activities, creation and revision of multiple drafts with rounds of peer and teacher feedback, final draft editing and proofreading, and postwriting (i.e., display or dissemi- 
nation) activities. This has become widely known as the process approach to writing and is commonly used and advocated for in various settings (Weigle, 2014). While the process approach to writing was not necessarily conceived as part of sociocultural theory, it is fully compatible with it, and can indeed be regarded as one of its integral aspects.

To summarize, from a sociocultural perspective, writing is a complex, mediated, distributed, and dialogic process of discovery and invention. Collaboration, feedback, and indeed coauthorship in the sense described above are assumed to benefit learners. In the 21st century, technology plays an important role in these processes. Studies and pedagogical overviews of integrating technology, sociocultural theory, and second or foreign language pedagogy already exist in the computer-assisted language learning (CALL) literature. For example, the use of wikis, blogs, and online sharing platforms such as Google Drive have generated a body of recent research (see, e.g., Aydin \& Yildiz, 2014; Kessler, Bikowski, \& Boggs, 2012; Kuteeva, 2011; Suwantarathip \& Wichadee, 2014; Yang, 2010). This article aims to augment this literature by offering further perspectives on the use of Google Drive.

\section{Google Drive: From Features to Affordances}

Google Drive is an integrated sharing and synchronization service available as a free Google app with 15 gigabytes of cloud storage. As of September 2014, Google Drive had over 240 million users worldwide (Griffith, 2014). With regard to writing, Google Drive's features are accessed through the Google Docs (sub)app and include document creation, storage, synchronous and asynchronous sharing, editing and commenting, revision histories (i.e., view of previous versions of a document owned by a single user or shared among users), document-specific real-time chat, and various distribution options across audiences and platforms. In the context of writing instruction, the app's features become affordances in the sense of van Lier (2000; see also Gibson, 1979). That is, using the existing general properties of the app with specific goals and purposes, grounded in sociocultural theory and a process approach to writing, affords the emergence of new pedagogical benefits.

Google Drive's affordances are different from those of traditional wordprocessing software. Overall, the former can be described as dynamic and the latter as static, and this has potentially powerful implications. For example, online document sharing allows instructors and peers to have a privileged view of the process of invention and creation in real time. That is, writers can be observed and can observe others as they write with Google Docs, something that traditional word-processing technology does not allow. Furthermore, instead of exchanging drafts and taking turns writing on them, students, their peers, and instructors can now collaborate dynamically in real time by "being" in the same document simultaneously. This affords generating ideas, writing new text, adding comments in the margins, making direct 
edits on shared texts, and chatting online with the other contributors. Every new word written from an individual user's device appears on the screen of the rest of the collaborators, bringing the dialogic, mediated, and collaborative processes underlying sociocultural theory to a new level. With regard to distribution and dissemination, Google Drive affords multiple options, ranging from keeping a document private to sharing it with the teacher, a group of peers, the whole class, or potentially whole communities around the world. Thus, intertextuality plays an important role as learners can borrow, interact with, modify, and influence both content and linguistic forms coming from various other users in the classroom and beyond.

The above nonexhaustive list of Google Drive's affordances with regard to writing instruction illustrates how the tool is fully compatible with and in fact can enhance sociocultural and process-oriented aspects of writing pedagogy. In the following section, I provide a template for designing a course with this tool and offer specific examples of tasks that can be used in this environment.

\section{A Sample Course Template}

Google Drive's affordances can be leveraged in various ways in the L2 writing classroom, using existing lab facilities or students' and instructors' individual resources (i.e., access to an Internet-enabled computer with a popular web browser, preferably Google Chrome). Below is a sample course template used at a postsecondary institution in North America. The course is designed for roughly $50 \%$ traditional face-to-face instruction and $50 \%$ lab or online instruction (i.e., a hybrid/blended course), but various other designs are possible. Some of the tasks and examples used are hypothetical, while others are authentic. The students in the examples below are not real and the class size is small for illustration purposes (for additional examples of Google Drive use in language teaching, see, e.g., Lin \& Yang, 2013; Thouësny \& Bradley, 2014).

The Google Drive interface is organized in folders, subfolders, and files. For the purposes of ESL writing instruction, I present a course space organized in five main areas (folders): (1) Individual Space, (2) Group Space, (3) Whole Class Space, (4) Materials and Resources Space, and (5) Teaching Space. These are illustrated in Figure 1.

Within the Individual Space folder, students registered in the course have subfolders (labeled with their names) where they work on and store individual writing tasks throughout the semester. A student's individual folder is not visible to the rest of the class, but is shared with the instructor. Thus, the instructor has both synchronous and asynchronous access to all the work a student does over the course of the semester. Figure 2 shows the individual folders of six hypothetical international students registered in an ESL writing class, and Figure 3 offers a view inside one of these individual folders with a sample list of the writing projects of a particular student, Gabriela, for the duration of a semester. 


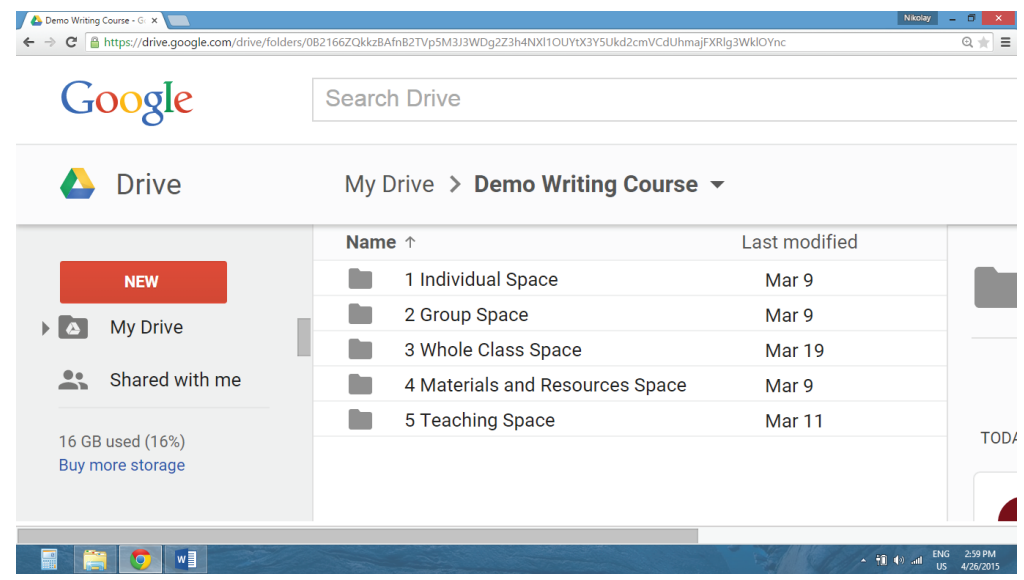

Figure 1. Course space, five main areas (folders).

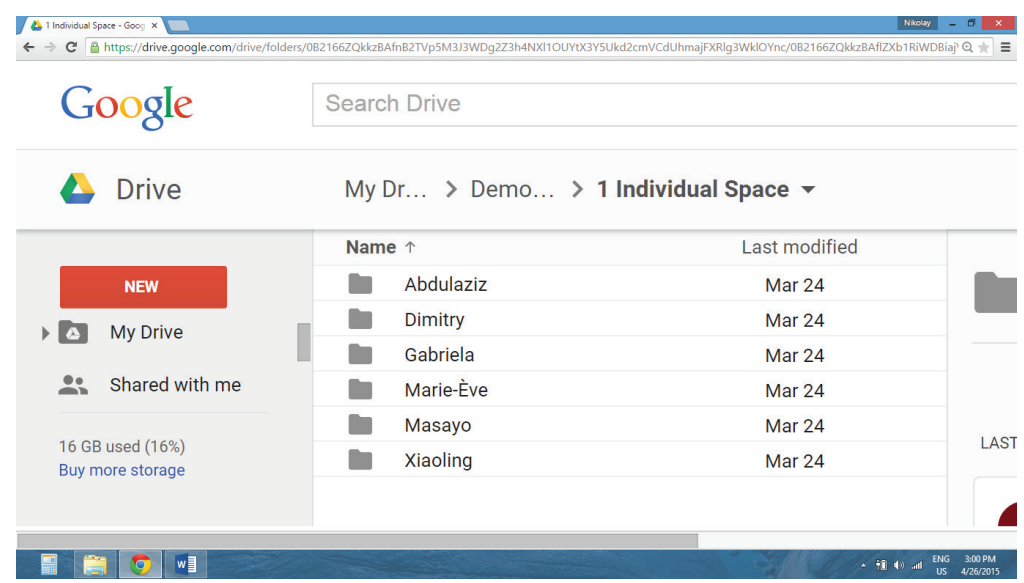

Figure 2. Individual space, student folders.

In terms of synchronous instruction, the instructor can monitor (from his or her own computer station at a lab, office, or home) students' writing activity during a class session and offer comments or corrective feedback in real time through the comment or live chat functions; the instructor can also choose to make direct edits in students' documents in real time, as they write. Because every character that a student types appears on the instructor's screen and vice versa, this constitutes an illustration of the dynamic collaboration and coauthorship affordance of Google Drive, not available with traditional word-processing software. As for asynchronous instruction, because all the work for the semester is stored in Google Drive, the instructor can check at any point if/when students have started working on an assignment, how 
they are progressing, what revisions they have made at which point, and how close they are to completion. This is done through the activity and revision history functions, which highlight the tool's compatibility with and indeed potential to advance the pedagogical view of writing as a process rather than a product, as discussed earlier.

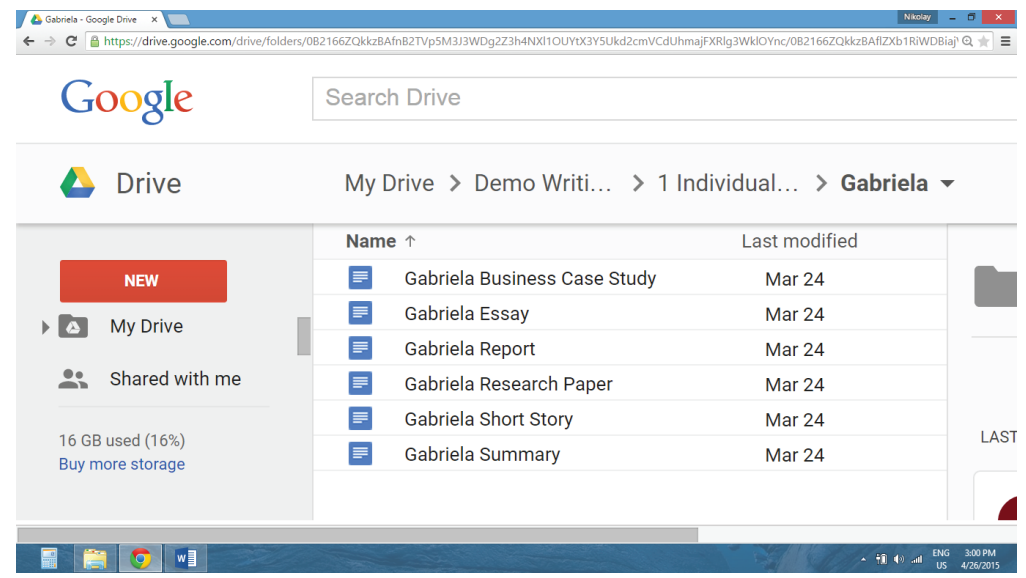

Figure 3. Gabriela's individual folder, list of sample writing projects.

The Group Space folder shows that students are assigned to pairs or small groups, with a subfolder corresponding to each group, as illustrated in Figure 4.

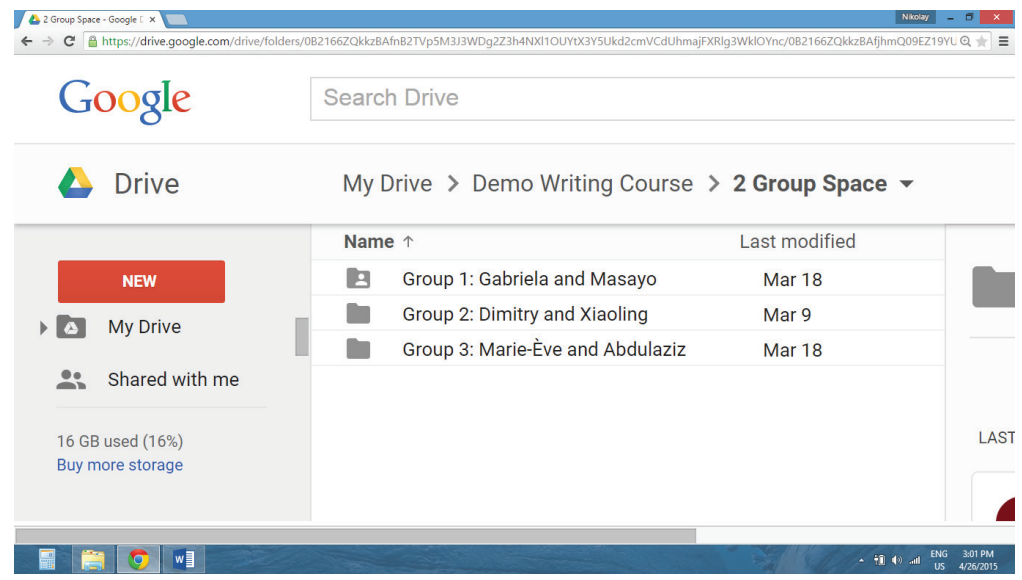

Figure 4. Group space, student pair folders for collaborative work. 
Looking inside Group 1's folder, we see that Gabriela and Masayo are working collaboratively on three different tasks, as illustrated in Figure 5.

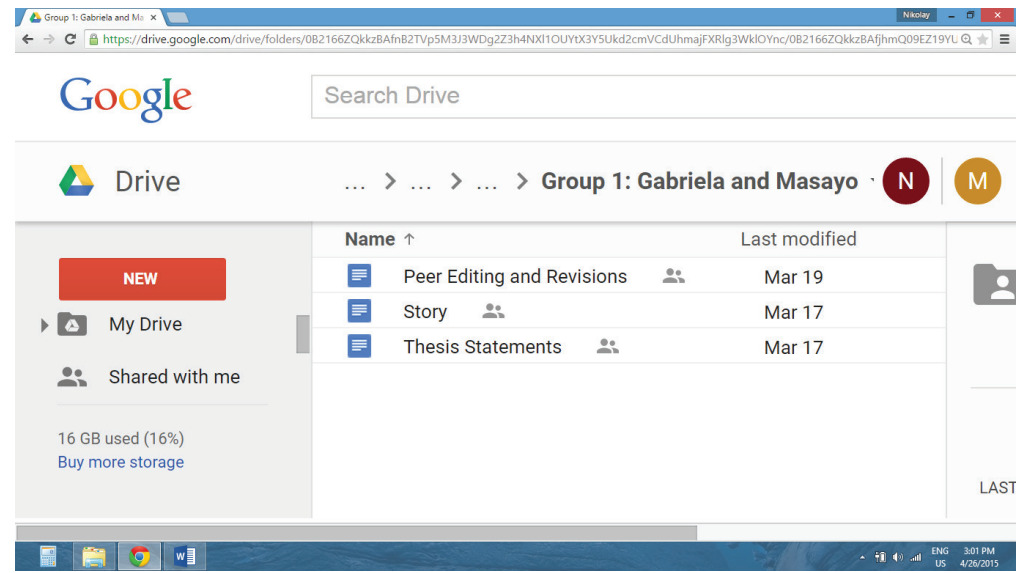

Figure 5. Group 1's collaborative tasks.

Students are given view and edit sharing privileges inside the group folders by the instructor; this is particularly suitable for peer editing, feedback, and collaborative projects. For example, we see that Gabriela and Masayo have three documents in their shared folder: a peer editing and revisions task, a story creation task, and a thesis statement development task. Figure 6 is a snapshot of the peer editing and revisions task shared by these two students.

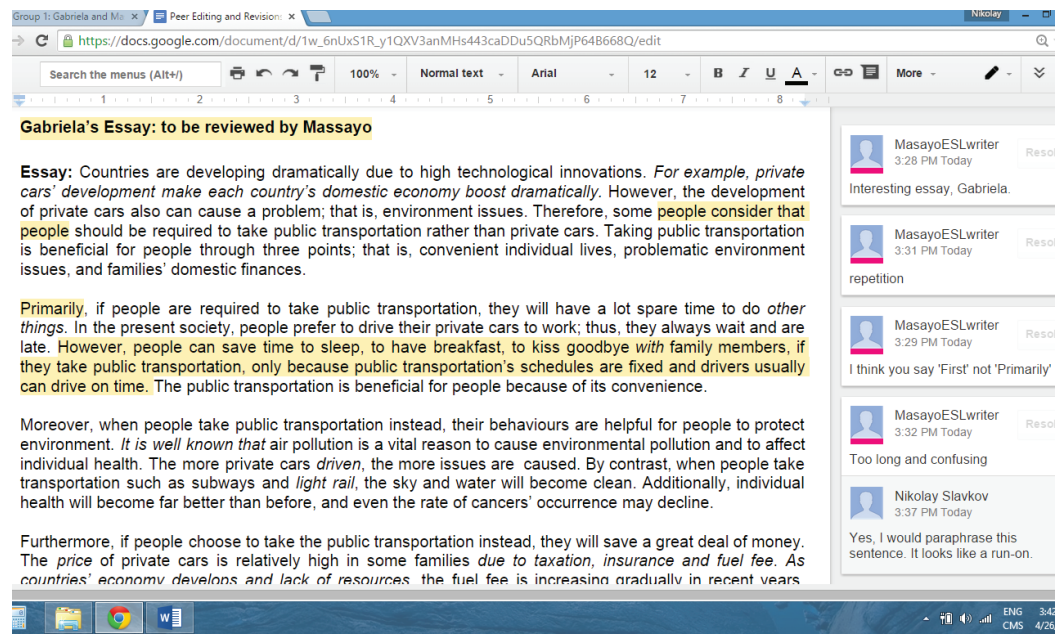

Figure 6. Group 1's peer editing and revision's task. 
Student pairs can work collaboratively during a class period (each from their own computer station in a lab or from home), or asynchronously as homework. Let us assume that in this particular case, Masayo asynchronously reviewed a completed draft of an essay written by Gabriela and commented on it. This was followed by instructor comments, which illustrates Google Drive's superior affordances with regard to process-driven and collaborative approaches to L2 writing; that is, the actors involved have continuous access and can contribute on an ongoing basis.

The third main area in the sample course space (recall Figure 1) is the Whole Class Space folder. As the label suggests, this is a shared folder among all students and the instructor, and all files placed in this folder can be viewed and edited by all users. Tasks in this area of the course space vary in appropriateness depending on class size; for example, although possible from a technological perspective, it may not always be useful for 20-30 students to open and work collaboratively on a single document in real time. Typically, exercises where students take turns in a preassigned order and make contributions to a document as the rest of the class watches in real time are appropriate for this area of the course space. Figure 7 illustrates an in-class exercise and a silly story creation task as examples of whole class activities.

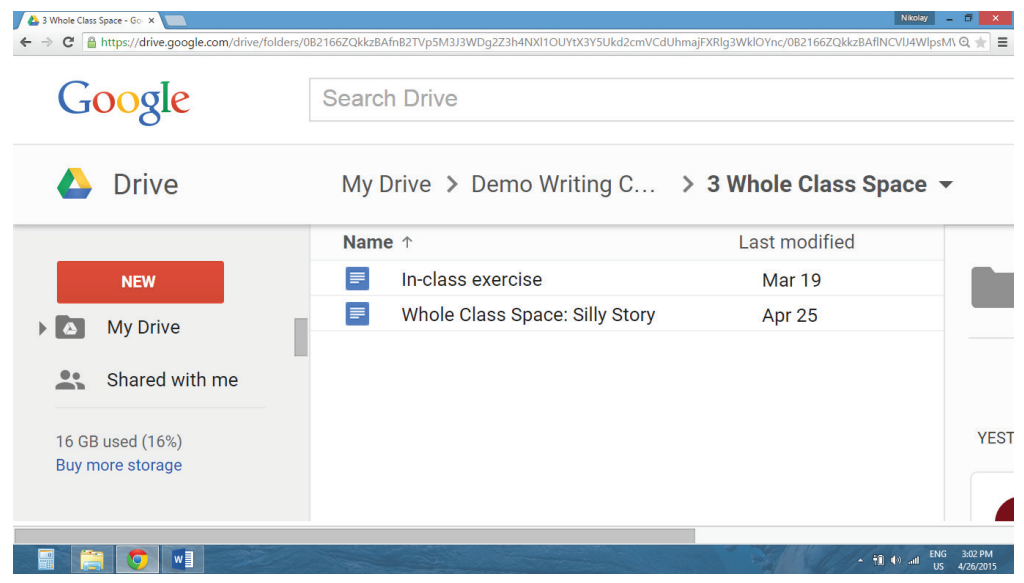

Figure 7. Whole class space, sample activities.

Various in-class exercises can be designed with regard to mechanics and L2 grammar, where all class participants can benefit from providing answers in turn and viewing everyone's contributions in real time; teacher feedback can be integrated easily through direct edits, comments, or using the chat function. I will not illustrate such activities due to space considerations, but will instead offer an example of the silly story creation task listed above. This is a modified version of an authentic small-group task for an advanced ESL 
credit course, but it can also be used successfully with larger class sizes and students at lower levels of proficiency. The purpose of the task is to create a silly story based on a list of vocabulary provided in advance. One student starts by choosing a vocabulary item from the list and writes the first sentence of the story as the entire class watches the words appear on their own screens. A second student then contributes another sentence after choosing another vocabulary item from the list, and so on. Once everyone has completed a turn, the story can end or continue with the first student again. A sample story created in this way and a sample comment by the instructor are shown in Figure 8. This type of collaborative writing affords a level of simultaneous group engagement that traditional word-processing does not; furthermore, under the premises of sociocultural theory, such group tasks may promote learning through a high level of engagement with multiple peers.

It was Saturday night. She was mesmerized by the sight of the stars in the sky. Then she saw a giant spider creeping on the wall beside her. She immediately unfolded her safety kit her boyfriend had given her as a present. She thought that killing the spider was the inescapable solution. She really is not the kind of girl who turns spider into deity. At this moment she had no predictability at all. Fortunately, she suddenly realized that the size of the spider had been magnified by the window right next to her. However, she still perceived the spider as a perturbation to her usual routine, so she couldn't leave it there. By serendipity, her brother came back from work at that very same moment. He got surprised because he noticed that his sister seemed to be savouring this scary moment. It almost felt like there was no resemblance at all between this woman and her little sister. Under the assumption that his sister was concentrated on the spider, he thought he had been unnoticed when he came in. He saw the emotional eddv in which his sister seemed to be.

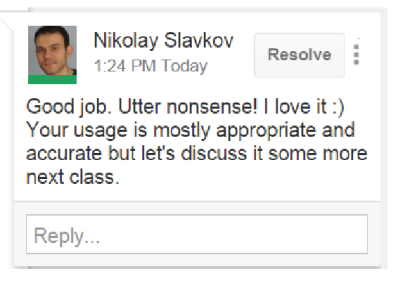

Figure 8. Whole class space, silly story.

Turning to the last two main areas of the sample course space, the Materials and Resources folder is used to post handouts, readings, and other materials and resources that students can access and use. The Teaching Space folder is reserved for the instructor to use as a virtual chalkboard. In this folder students have view-only access and cannot make direct edits to the documents. When the instructor needs to write something on the "chalkboard," he can open a document in this folder and ask students to watch on their screens as 
he types. This can be used, for example, if the instructor wants to discuss a quiz in real time, as the students watch the answers appear on their screens (as opposed to providing an answer key, which is a more static option). More details about these folders are not provided due to space considerations.

Before concluding this section, I would like to acknowledge that the use of technology in the classroom may pose certain challenges. For example, one can assume that not all teachers and learners are technology-savvy enough to benefit from the affordances that the online tool discussed in this article offers. This brings us to the general notion of digital literacies, which involves not only the technical skills but also the higher-order abilities to locate, prioritize, process, manage, analyze, or simply use information in the context of a fast-paced world influenced by the Internet and digital technology (for further discussion see, e.g., Glister, 1997; Tagg, 2015). In this broader context, the use of Google Drive in the classroom should not be reserved only for those with higher-level technical skills but should be considered a core digital literacy that needs to be acquired widely. To offer a simple comparison, the use of traditional offline word-processing software such as MS Word is nowadays seen as imperative in both educational and professional contexts, and individuals who are unable to use such software are clearly at a disadvantage. ${ }^{4}$ I believe similar reasoning will soon apply to the next generation of technological tools, including Google Drive; thus, educators and students alike need opportunities to become literate in such tools in order to be better prepared for the future realities that they may need to face.

\section{Discussion and Conclusion}

L2 instruction and practice employing Google Drive highlights the sociocultural view of writing as a type of social act that involves a complex, distributed, mediated, and dialogic process of invention and language skill development (Bazerman \& Prior, 2004; Behizadeh, 2014; Dyson, 1993, 1997; Prior, 2006; Razafar \& Gutierrez, 2003; Rish et al., 2015; Schultz \& Fecho, 2000). On the assumption that emerging L2 writers benefit from continuous peer and teacher feedback and authentic collaborative tasks, Google Drive offers a rich new learning environment. It surpasses the capabilities of traditional word-processing technology and acts as a mediation and distribution tool in the complex socially situated process of linguistic and cultural discovery. It offers various opportunities for distribution to single or multiple other users at the prewriting, drafting, revision, and postwriting stages of the writing process. It challenges the traditional idea of a submission of a final draft of a writing assignment, as the instructor has a privileged continuous view of the development of students' writing projects both in class and over the course of the semester. The fact that the tool does not have a "Save File" button means that student work is already "submitted" and can be viewed by the instructor, and potentially by student peers, while still in progress. 
In terms of the dialogic aspect of writing (Bakhtin, 1981), Google Drive allows students and the instructor to interact in multiple and complex ways. In addition to collaborative tasks and coauthorship, the tool allows learners to "watch" the instructor as he provides feedback. For example, in my teaching I allow students to "watch" in real time as I grade final drafts of writing assignments; thus students get a glimpse of how an instructor drafts, revises, edits, and prioritizes comments and corrections. This also allows students to react, seek further clarifications, or even challenge some of the comments or critique, thus bringing the idea of a dialogue to a new level. In this respect, the use of online technology affords a higher degree of immediacy and interactivity than a traditional offline word-processed submission returned to the students at a later point with teacher comments in the margins (often still printed on paper).

As for intertextuality, Google Drive has the capacity to create multiple complex sharing networks connecting texts, ideas, and discourses across individual users, small groups, whole classrooms, and potentially entire communities of practice. This type of intertextual connectedness, theorized in the context of the previous century (Bakhtin, 1981; see also Bazerman, 2004; Fairclough, 1992), has now reached an unprecedented degree of development in an era defined by online technology. In the context of the L2 writing classroom, learners can benefit from easy access to multiple examples of linguistic structures and vocabulary as well as samples of various writing genres embodying relevant discourses and cultural conventions in context. New teaching and learning opportunities for L2 writing development can be found in such rich and still relatively underused domains.

In conclusion, even though at a first glance Google Drive, sociocultural theory, and L2 writing may not seem interconnected in obvious ways-and clearly were not conceived with one another in mind - they are not strange bedfellows (see Anh \& Marginson, 2013, for a similar proposal). If we adopt a sociocultural view of humans as collaborative social actors, we can regard the design and creation of Google Drive as an epiphenomenon of basic human nature, a by-product of human functions and processes in a world increasingly mediated by technological artefacts. In this respect, Google Drive does not only enhance but may eventually permeate modern L2 writing instruction.

\section{Notes}

1 The term affordance refers to a particular feature or property of a tool, object, or environment that allows specific uses or benefits with regard to achieving overall objectives (see van Lier, 2000, for more details on how the term applies to language teaching; see also the section on Google Drive in this article).

2 Note that the notion of intertextuality originally proposed by Bakhtin (1981) may be defined and interpreted in various ways. In this article, I use it in the broad sense described above. For further discussion and definitions of the term, the readers are referred to Fairclough (1992, p. 84) 
and Bazerman (2004, p. 86), among others. I thank an anonymous reviewer for raising this point and suggesting the additional references.

3 This article focuses on the basic Google Drive app available for general public use, and not on the recently released Google Classroom module designed specifically for educational institutions.

4 Note that what I call "traditional" word-processing software in this article is also undergoing a rapid process of evolution. For example, MS Word now also has an online version offering many of the capabilities described in the previous section.

\section{Acknowledgements}

Earlier versions of this work were presented and benefited from useful comments at the World Congress of Modern Languages (2015) in Niagara Falls, ON, and at one of the meetings of the University of Ottawa's Interdisciplinary Research Group in Languages \& Technologies (2015). I am also very grateful to the three anonymous TESL Canada reviewers for their timely, thorough, and insightful remarks and suggestions. The student participants who kindly gave permission for their work to be used as samples were the source of both data and inspiration for this article.

\section{The Author}

Nikolay Slavkov is an Assistant Professor at the Official Languages and Bilingualism Institute at the University of Ottawa. His research interests are in bilingual and multilingual child language development, family language policy, adult second language acquisition, language teaching pedagogy, and technology.

\section{References}

Anh, D. T. K., \& Marginson, S. (2013). Global learning through the lens of Vygotskian sociocultural theory. Critical Studies in Education, 54(2), 143-159.

Aydin, Z., \& Yildiz, S. (2014). Using wikis to promote collaborative EFL writing. Language Learning \& Technology, 18(1), 160-180.

Bakhtin, M. M. (1981). The dialogic imagination: Four essays by M. M. Bakhtin (C. Emerson \& M. Holquist, Trans.). Austin, TX: University of Texas Press.

Bazerman, C. (2004). Intertextuality: How texts rely on other texts. In C. Bazerman \& P. Prior (Eds.), What writing does and how it does it: An introduction to analyzing texts and textual practices (pp. 83-96). Mahwah, NJ: Lawrence Erlbaum.

Bazerman, C., \& Prior, P. (Eds.). (2004). What writing does and how it does it: An introduction to analyzing texts and textual practices. Mahwah, NJ: Lawrence Erlbaum.

Behizadeh, N. (2014). Mitigating the dangers of a single story: Creating large-scale writing assessments aligned with sociocultural theory. Educational Researcher, 43(3), 125-136.

Dyson, A. H. (1993). Social worlds of children learning to write in an urban primary school. New York, NY: Teachers College Press.

Dyson, A. H. (1997). Writing superheroes: Contemporary childhood, popular culture, and classroom literacy. New York, NY: Teachers College Press.

Eun, B., \& Lim, H.-S. (2009). A sociocultural view of language learning: The importance of meaning-based instruction. TESL Canada Journal, 27(1), 12-26.

Fairclough, N. (1992). Discourse and social change. Cambridge, UK: Polity Press.

Ferris, D. R., \& Hedgcock, J. S. (2013). Teaching ESL composition: Purpose, process, and practice (3rd ed.). New York, NY: Routledge.

Gibson, J. J. (1979). The ecological approach to visual perception. Boston, MA: Houghton Mifflin.

Glister, P. (1997). Digital literacy. New York, NY: John Wiley \& Sons.

Griffith, E. (2014, November 6). Who's winning the consumer cloud storage wars? Fortune. Retrieved from http://fortune.com/2014/11/06/dropbox-google-drive-microsoft-onedrive/ 
Hyland, K. (2003). Genre-based pedagogies: A social response to process. Journal of Second Language Writing, 12(1), 17-29. doi:10.1016/S1060-3743(02)00124-8

Kalan, A. (2014). A practice-oriented definition of post-process second language writing theory. TESL Canada Journal, 32(1), 1-18.

Kessler, G., Bikowski, D., \& Boggs, J. (2012). Collaborative writing among second language learners in academic web-based projects. Language Learning \& Technology, 16(1), 91-109.

Kuteeva, M. (2011). Wikis and academic writing: Changing the writer-reader relationship. English for Specific Purposes, 30(1), 44-57. doi: 10.1016/j.esp.2010.04.007

Lantolf, J. P. (1994). Sociocultural theory and second language learning: Introduction to the special issue. Modern Language Journal, 78(4), 418-420. doi:10.1111/j.1540-4781.1994.tb02058.x

Lantolf, J. P. (Ed.). (2000). Sociocultural theory and second language learning. Oxford, UK: Oxford University Press.

Lantolf, J. P., \& Thorne, S. L. (2006). Sociocultural theory and the genesis of second language development. Oxford, UK: Oxford University Press.

Leki, I., Cumming, A., \& Silva, T. (2008). A synthesis of research on second language writing in English. London, UK: Routledge.

Lin, W.-C., \& Yang, S. C. (2013). Exploring the roles of Google.doc and peer e-tutors in English writing. English Teaching: Practice and Critique, 12(1), 79-90.

Matsuda, P. K. (2003). Second language writing in the twentieth century: A situated historical perspective. In B. Kroll (Ed.), Exploring the dynamics of second language writing (pp. 15-34). New York, NY: Cambridge University Press.

Peñuelas, A. B. C. (2008). A comparison of an effective and an ineffective writer's mental representations of their audience, rhetorical purpose and composing strategies. Revista Electrónica de Lingüística Aplicada, 7, 90-104.

Prior, P. (2006). A sociocultural theory of writing. In C. A. MacArthur, S. Graham, \& J. Fitzgerald (Eds.), Handbook of writing research (pp. 54-66). New York, NY: Guilford Press.

Razafar, A., \& Gutiérrez, K. (2003). Reconceptualizing early childhood literacy: The sociocultural influence. In N. Hall, J. Larson, \& J. Marsh (Eds.), Handbook of early childhood literacy (pp. 34-47). Thousand Oaks, CA: Sage.

Rish, R. M., Bylen, K., Vreeland, H., \& Wimberley, C. C. (2015). Using Google Drive to write dialogically with teachers. In M. L. Niess \& H. W. Gillow-Wiles (Eds.), Handbook of research on teacher education in the digital age (pp. 357-379). Hershey, PA: IGI Global. doi:10.4018/9781-4666-8403-4

Sasaki, M. (2000). Toward an empirical model of EFL writing processes: An exploratory study. Journal of Second Language Writing, 9(3), 259-291.

Schultz, K., \& Fecho, B. (2000). Society's child: Social context and writing development. Educational Psychologist, 35(1), 51-62.

Suwantarathip, O., \& Wichadee, S. (2014). The effects of collaborative writing activity using Google Docs on students' writing abilities. Turkish Online Journal of Educational Technology, 13(2), 148-156.

Tagg, C. (2015). Exploring digital communication: Language in action. New York, NY: Routledge.

Thouësny, S., \& Bradley, L. (2014). Applying dynamic assessment principles to online peer revisions in written English for specific purposes. In S. Jager, L. Bradley, E. J. Meima, \& S. Thouësny (Eds.), CALL design: Principles and practice; Proceedings of the 2014 EUROCALL Conference, Groningen, The Netherlands (pp. 368-373). Dublin, Ireland: Research-publishing. net. doi:10.14705/rpnet.2014.000247

van Lier, L. (2000). From input to affordance: Social-interactive learning from an ecological perspective. In J. P. Lantolf (Ed.), Sociocultural theory and second language learning: Recent advances (pp. 245-259). Oxford, UK: Oxford University Press.

Villamil, O. S., \& de Guerrero, M. C. M. (2006). Sociocultural theory: A framework for understanding the social-cognitive dimensions of peer feedback. In K. Hyland \& F. Hyland 
(Eds.), Feedback in second language writing: Contexts and issues (pp. 23-41). Cambridge, UK: Cambridge University Press. doi:10.1017/CBO9781139524742.004

Vygotsky, L. S. (1978). Mind in society: The development of higher psychological processes. Cambridge, MA: Harvard University Press.

Vygotsky, L. S. (1986). Thought and language. Cambridge, MA: MIT Press.

Weigle, S. C. (2005). Second language writing expertise. In K. Johnson (Ed.), Expertise in language learning and teaching (pp. 128-149). Hampshire, UK: Palgrave Macmillan.

Weigle, S. C. (2014). Considerations for teaching second language writing. In M. Celce-Murcia, D. M. Brinton, \& M. A. Snow (Eds.), Teaching English as a second or foreign language (4th ed., pp. 222-237). Boston, MA: National Geographic Learning.

White, R. V., \& Arndt, V. (1991). Process writing. New York, NY: Longman.

Williams, J. (2005). Teaching writing in second and foreign language classrooms. Boston, MA: McGraw-Hill.

Yang, C. C. R. (2010). Using Google Docs to facilitate collaborative writing practice in an English language classroom practice. TESL-EJ, 14(3), 1-8.

Yoon, B., \& Kim, H. K. (Eds.). (2012). Teachers' roles in second language learning: Classroom applications of sociocultural theory. Charlotte, NC: Information Age Publishing. 